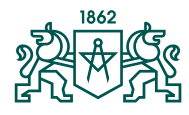

RIGA TECHNICAL UNIVERSITY
No. 4 , Sept. 2020 , pp. 9-30 https://doi.org/10.7250/HESIHE.2020.002

\title{
PRODUCTION OF HORSE-DRAWN CARRIAGES IN LATVIA IN THE 20TH CENTURY
}

INDULIS ZVIRGZDIN̦Š

Latvian Association for the History of Science

\begin{abstract}
Summary. In the first half of the last century, wood craftsmen and blacksmiths collaborated in the manufacture of carriages, but in most cases they worked individually. There were also larger companies operating mainly in cities. The author's main focus is on the Madona area. The carriage and sled workshop of Augusts Mazurs (1885-1975), which was the most significant in the area, is used as an example. It was established in 1924 and continued its work during the Soviet era.

Horse-drawn carriages were the main mode of local transport in the Republic of Latvia and its territory also in the decade after World War II. Later, the role of road transport gradually increased. Carriages and sleds were made on site, most cars were imported.
\end{abstract}

Keywords: horse-drawn transport, carriage makers, woodworking, Latvian Chamber of Crafts, Augusts Mazurs.

\section{Introduction}

In the middle of the 20th century, a car gradually replaced horsedrawn carriages in land transportation in Latvia. Railway was used for longer distance transportation. In the Republic of Latvia, before World War II, horse-drawn carriages undoubtedly played a key role, especially in the countryside. Cars and fuel for them were mainly imported, while carriages were made on site. The comparison of different means of transport - horse-drawn carriages, tractors, cars - was performed at the Labour Research Institute of the Ministry of Agriculture in Lielplatone (Head - graduate of the University of Latvia (UL), agronomist Jānis Jānitis (1903-?)) [1]. It has been concluded that for short distances transportation, especially within a single farm, horse-drawn carriages

\footnotetext{
* Corresponding author.

E-mail: zviindulis6@inbox.lv

(C) 2020 Indulis Zvirgzdinšs. Publisher RTU Press.

This is an open access article licensed under the Creative Commons Attribution License

(http://creativecommons.org/licenses/by/4.0/).
} 
are cheaper and more cost-effective in use than internal combustion engines.

The car can be used all year round, but horse-drawn vehicles differ in summer and winter. In the climatic conditions of Latvia, the use of carriages for a farmer during the year was relatively longer, while their production was more complicated compared to making sleds. Some of transportation - manure, hay, cereals, and timber - was seasonal. In the 1930s, it was also the delivery of sugar beet in the autumn. The carriages were also used to transport milk to dairies, both individually and in collaboration by several farmers. Sometimes special carriages were made for certain works, for example, for transporting stones, logs, straw. The author of the study traced the use and production of horsedrawn carriages in Latvia in the first half of the 20th century, based on the collections of Latvian libraries and museums, as well as archival documents.

The aim of the article is to reveal the results of the research on the development of horse-drawn carriage transport in Latvia, using A. Mazurs' carriage and sled workshop as an example and describing its activities in Madona city.

\section{Manufacture and Use of Carriages}

The construction of various carriages in the territory of presentday Latvia has developed over a long period of time. The outline of the carriage (Figure 1) drawn by Johann Christoph Brotze (1742-1823), an artist, ethnographer, historian and educator of the Enlightenment in the second half of the 18th / early 19th century, can be seen with relatively small changes after a century and a half, although the use of metal parts has increased over the years. The German-Baltic pastor and linguist August Bielenstein (1826-1907) pointed out in his work on Latvian wooden objects that in the second half of the 19th century the carts were often made by the peasants themselves, and described these work processes [2].

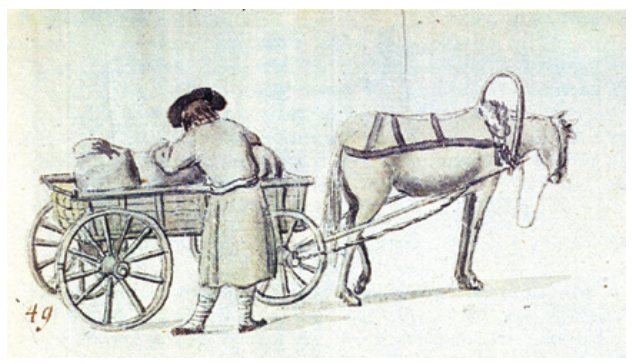

Figure 1. A peasant from Gulbene congregation goes to the city. Drawing by J. C. Brotze. 
In 1929, 137257 wooden and 177197 iron axle carts were registered in Latvia, respectively $43.65 \%$ and $56.35 \%$ [3]. In Latgale, wooden axle carts accounted for $72.3 \%$ of the total number. Jānis Ābolinšs (19061990), a graduate of the Faculty of Engineering of the UL (1930), then a lecturer in the Faculty of Agriculture, made a detailed description of agricultural vehicles. For this achievement he received the Krišjānis Barons Prize in 1936 (from 1926 to 1940, the prize was awarded for scientific research in Latvian nature and culture, funded from the Award Fund of the Ministry of Education). Information on most of Latvia's parishes has been collected, mentioning dairies, parish boards and fairs as the main places where different carriages could usually be seen at the same time. About $17 \%$ of them were transport vehicles - coaches, line-carts, and dogcarts, while less than a tenth part were carriages and pairs, which are more common in Kurzeme. J. Ābolinš divided the universal carriages of general transport works into five basic types: rustic horse cart (Figures 2, 3), raspuskas, Kurzeme work carriages, Latgale work carriages and Estonian slatted carriages.

Figure 2. Rustic horse cart in work in Lubāna. Photo by A. Grāvers (1930).

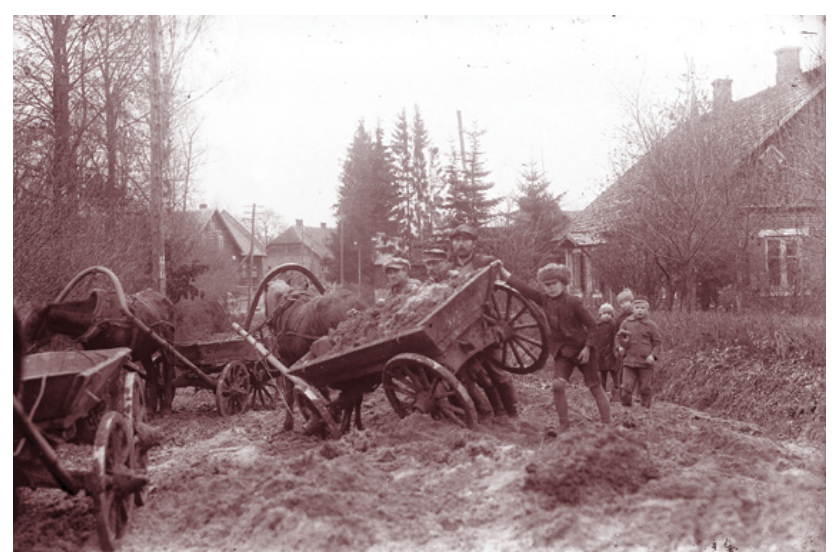

Figure 3. Rustic horse cart in Lubāna. Photo by A. Grāvers (circa 1930).

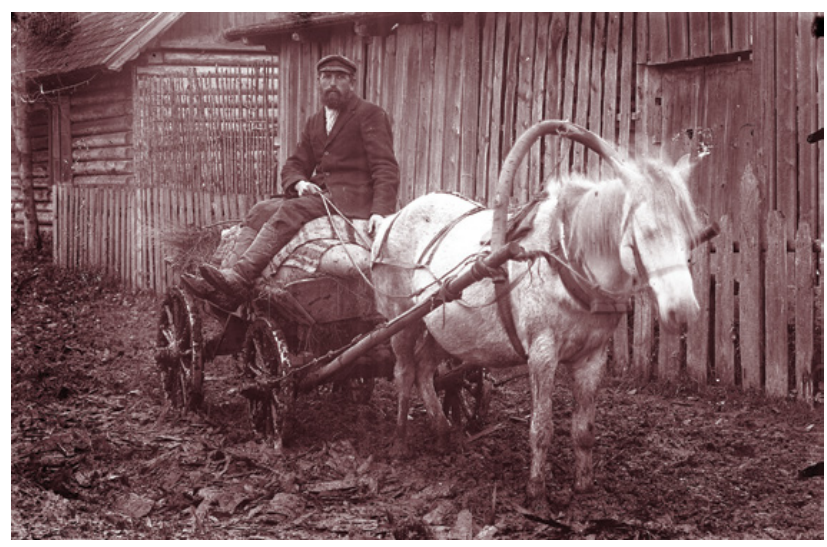


The rustic horse cart include the historically older ones, also those drawn by J. C. Brotze. The Priekuli agricultural machinery station had already recommended to introduce raspuskas before World War I. The literary dictionary reads: «Raspuska (old) - a work carriage with a wide surface, steel-clad wheels and a flat, raised floor above the wheels under which the axle of the front wheels can rotate freely» [4]. Compared to the rustic horse cart, they were slightly heavier, the raspuska had more metal mountings. A new raspuska made in the city cost 140-180 lats, made in the countryside - 100-140 lats [5; p. 11.]. Latvian Government issued an order, which set prices for horses, vehicles and their accessories that were mobilized for military needs. From 1923, it was 108 lats for one-horse iron axle carriages [6]. In the 1930s, this price was a quarter lower. Used carts were also submitted for mobilization, so the average payment was lower than that for new ones.
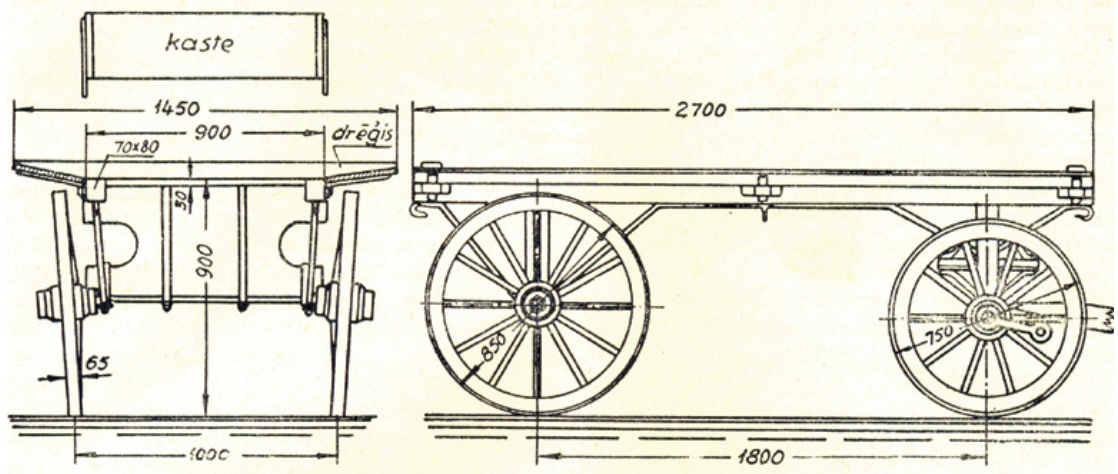

Figure 4. Raspuska. Drawing by J. Āboliņ̌s (circa 1936).

Different masters made carriages of about similar size - the length, width, distance between the wheels and diameter were about the same. There were no set standards, so not everywhere it was possible to use prefabricated parts. They were offered in the 1930s, for example by «The First Riga Wheel Springs and Axles Factory I. M. Kraner» [7].

The suitability of agricultural machinery was also assessed at the Labour Research Institute in Lielplatone. A model for general-purpose carriages with so-called balloon-type tires was developed there [8]. After that, the wheels of the car sample had tires with inflatable tubes and the rotation of the wheels around the axle was facilitated by bearings. Elsewhere in Europe, such vehicles have been used much earlier. The carriage was designed for one or two horses. Thanks to these improvements, their load capacity increased significantly. Such carriages also had less effect on the road surface, but they were more difficult 
to make. The production of such carriages with imported tires was undertaken by the Liepāja War Port Workshop (later - JSC «Tosmare»). By the end of 1939, about 600 rubber tires were made there. It was possibly to make carriages with balloon tires also manually, but then their costs were relatively high. Engineer J. Ābolin,š evaluated the types of Latvian work carriages and concluded that «.. raspuskas were recognized as best. They are the most versatile work carriages that can be quickly and easily applied in all agricultural transportation works at home and outdoors [5; p. 93].»

Depending on the load being transported and the road conditions, the wheels were particularly exposed to different loads. They soon broke and had to be repaired or replaced. In fairy tales, travellers also needed help if they carriage wheel broke. Making a carriage wheel was more complicated and required more specific tools than other parts of the carriage. The wheel consisted of a wooden hub, spokes and a rim. They were reinforced with iron parts. The hub was usually turned from oak, with a hole drilled in the centre to put it on the shaft. In the thickest part of the hub, perforations perpendicular to the axis were drilled for driving the spokes, the oak spokes were fixed in the still hot hub after stewing it for several hours. The number of spokes ranged from 8 to 12 depending on the diameter of the wheel. To prevent the hub from cracking, heated rings were applied to it, while cooling they covered the wooden part more tightly. A metal ring was also inserted into the borehole, which wore out more slowly as it rotated around the axis.

The wheel rim was made either in one piece or from individual sections. An ash tree was usually used for the one-piece rim, after several days of stewing, bending was done with a special device. Another option was to cut the arch sections from ash or birch. One wheel was made of 4-5 identical arc fragments, fastened with special clamps. It was easier to place the arc on the spokes in several sections, but that would decrease the endurance. In both cases, the wheel was covered with a metal hoop that had direct contact with the road surface. The hoop was also placed on the wheel heated and secured with bolts passed through the rim.

The so-called plācis (area name - the part of the carriage placed above the axle), to which axles were attached at the bottom, but the platform of the carriage was attached on top, were cut from birch. At the bottom and on top of the front two-piece plācis, metal disc rings were fixed to each other to ensure axle rotation. The carriage platform was usually made of spruce or pine wood.

«Statistical Yearbook of Latvia» prepared by the State Statistical Bureau lists carriage workshops with five or more employees and those that used a mechanical engine. In 1935, all workshops producing 
carriages, sleds, toboggans, and wheels were listed, so it is not possible to find only manufacturers that produced only carriages.

Table 1

Carriage workshops (1925-1939) with five or more workers [9]

\begin{tabular}{|l|c|l|l|l|l|l|}
\hline & \multirow{2}{*}{$\begin{array}{l}\text { Yumber } \\
\text { Yo enter- } \\
\text { prises }\end{array}$} & Total & $\begin{array}{l}\text { Number of employees } \\
\text { Of these, } \\
\text { workers }\end{array}$ & $\begin{array}{l}\text { Value of } \\
\text { products } \\
\text { (thou- } \\
\text { sands of } \\
\text { lats) }\end{array}$ & $\begin{array}{l}\text { Salaries } \\
\text { (thou- } \\
\text { sands of } \\
\text { lats) }\end{array}$ & $\begin{array}{l}\text { Raw } \\
\text { materials } \\
\text { thou- } \\
\text { sands of } \\
\text { lats) }\end{array}$ \\
\hline 1925 & 5 & 61 & 58 & & & \\
\hline 1926 & 11 & 56 & 52 & 108 & & \\
\hline 1927 & 12 & 62 & 53 & 112 & & \\
\hline 1928 & 10 & 67 & 56 & 183 & 49 & 66 \\
\hline 1929 & 11 & 62 & 50 & 158 & 45 & 71 \\
\hline 1930 & 11 & 82 & 66 & 168 & 59 & 65 \\
\hline 1931 & 12 & 63 & 50 & 110 & 42 & 37 \\
\hline 1932 & 14 & 52 & 36 & 85 & 28 & 24 \\
\hline 1933 & 14 & 74 & 56 & 102 & 42 & 32 \\
\hline 1934 & 15 & 92 & 73 & 144 & 49 & 50 \\
\hline 1935 & 52 & 137 & 76 & 199 & 58 & 56 \\
\hline 1936 & 47 & 134 & 76 & 221 & 66 & 73 \\
\hline 1937 & 43 & 100 & 54 & 173 & 49 & 72 \\
\hline 1938 & 50 & 114 & 60 & 217 & 61 & 81 \\
\hline 1939 & 57 & 132 & 57 & 253 & & \\
\hline
\end{tabular}

It must be assumed that the rapid growth of carriage workshops in 1935 was due to a change in accounting criteria - then the table no longer mentions a limit of at least five employees. That year, the general census of Latvian economic enterprises was also conducted. Of the 989 carriage workshops listed in Latvia in 1935, 759 workshops with 861 employees were located in rural areas and 230 workshops with 379 employees were located in cities [10]. This confirms once again that most carriage makers worked individually and that there were workshops with more employees in the cities. In 1935, 45 workshops were mentioned separately, which made sled runners and horse arches. 82 employees worked there. 
The occasional use of parts made elsewhere by the carriage makers is evidenced by the case of the ship «Fridrih», which allegedly ran aground on 3 July 1931 [11]. A two-masted sailboat was on its way from Liepajja to Riga transporting carriage wheel arches and sled runners - separate parts to be used in manufacturing of carriages and sleds. They had been received in Liepāja by H. Buklāns (?-?) and «Brāli Hilmanni» wood processing companies. The addressee in Riga was not mentioned. According to the documents, there were 725 wheel arches and 730 runners in the cargo space, and 3650 wheel arches and 255 runners were stacked on board. The cargo was insured for 17840 lats, according to these calculations, the wheel arch was valued at around three lats, the sled - less than three lats.

In 1936, the Latvian Chamber of Crafts was established, which to some extent supervised and regulated the activities of companies that were not considered to relate to industry (there was also a Chamber of Commerce and Industry). One of the sections of the Latvian Chamber of Crafts was the Woodworking Crafts Section. It comprised crafts of different fields: carpenters, basket and furniture weavers, barrel makers, toy makers, stick and umbrella makers, comb and brush makers, pattern-turner (carpenters specializing in molds), turners and carriage makers. Pēteris Lūsis (1901-1968) was Head of the section (1936-1940) and his deputy was Augusts Mazurs (also, Mazūrs; 1885-1975) from Madona [12]. P. Lūsis graduated from secondary school and had studied in the Department of National Economy of the UL for two years. Over the time, he took over the management of carriage and car bodywork workshop at 1 Puškina Street in Rigga of his father-in-law Vilis Paluks. The other members of the section were mostly carpenters.

In the Latvian Conversion Dictionary, the term «carriage maker» is explained as follows: «.. a craftsman who makes wooden parts for carriages, sleds, sledges and agricultural tools (plows, harrows, etc.). Usually carriage maker also makes trolleys, spools, and weaving tools» [13]. The work of a blacksmith was also important in making the carriages. In the countryside, craftsmen usually collaborated with particular blacksmiths who made the necessary metal parts for them, in larger workshops metal processing was made on site, or ready-made parts were used.

In the second half of the 1930s, in the south-western part of Madona District (in the north-east there was Gulbene Society), the following carriage makers were listed in the Crafts Society: Jānis Auzin̄š (?-?) in Lazdona «Upeskalvāres»; Pēteris Bikernieks (?-?) in Kusa «Škūri»; Valfrīds Duks (?-?) in Kraukḷi «Ziemel̦i»; Pēteris Caune (?-?) in Vējava «Pilskalni»; Silvestrs Gaigalnieks (?-?) in Meirāni «Lāčplēši»; Pēteris Grāvītis (?-?) in Liezēre «Grāvī̌ši; Jānis Alfreds (?-?) in Kazaks Dzelzava «Ozolsalas»; 
Osvalds Kurmis (?-?) in Kraukli «Tirzbānurti»; Jēkabs Maldups (?-?) in Kārzdaba «Mežkurēni»; Roberts Mednieks (?-?) in Lubāna «Gobiñas»; Alberts Mūrmanis (?-?) at 11 Brīvības Street, Lubāna; Jānis Priednieks (?-?) in Grostona «Bēci»; Pēteris Rozentāls (?-?) in Vestiena «Piejūti»; Jānis Stenders (?-?) in Prauliena «Imanti»; Jānis Vestfāls (?-?) in Kusa; and Jānis Viggants (?-?) in Medzūla «Ezerlī̌ci» [14]. It must be said, that the Society did not unite all those working in the respective sector. Jānis Jaunrubenis (?-?), Augusts Mazurs (1885-1975), Jānis Rakulis (?-?), Jānis Sausiņ̌ (1909-1974), Jānis Sproǵis (1857-?), Jānis Sproǵis (1903-1942) and Pēteris Sprogiis (?-?) are listed as carriage makers in the city of Madona.

A carriage workshop of Jannis Pinnis (1864-1941), the father of the outstanding Latvian painter Rūdolfs Pinnis (1902-1992), operated in Lubāna.

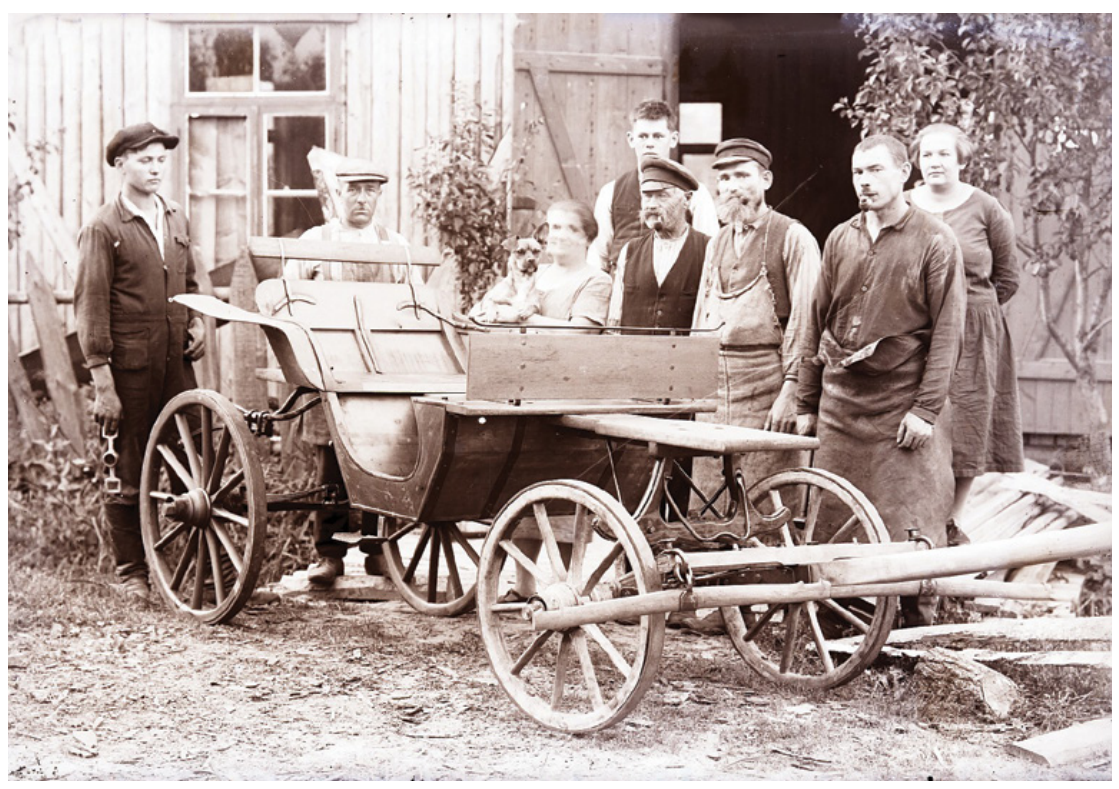

Figure 5. Carriage workshop of Jānis Pinnis in Lubāna. The owner of the carriage J. Pinnis with the workers at the unfinished coach. Photo by A. Grāvers (circa 1930).

\section{Augusts Mazurs' Carriage and Sled Workshop}

A. Mazurs ran a relatively large company - carriage and sled workshop. It is known that Jānis Sausiñš (1909-1974) and Jānis Sproǵis (1903-1942) worked in it and most likely others, too. The record of the birth of J. Sprogis made on 26 May 1903 in the Lazdona Lutheran Congregation in «Podniekkalns», Prauliena Parish, states that his father 
Jānis is a carriage maker [15]. J. Sproǵis' widow Berta Sproǵe 45 years after her husband's death said that her father-in-law mainly made carriage wheels [16]. J. Sprogis learned his craft skills from his father and later, until 1939, worked in A. Mazurs' workshop, and then started making carriage wheels individually. In 1940, J. Sprogis was one of the Soviet activists of Madona, he also became Head of the Craftsmen's Society at that time. Before the invasion of the German troops he evacuated to Russia and being a soldier of the Red Army fell near Staraya Rusa.

Figure 6. Augusts Mazurs (circa 1905).

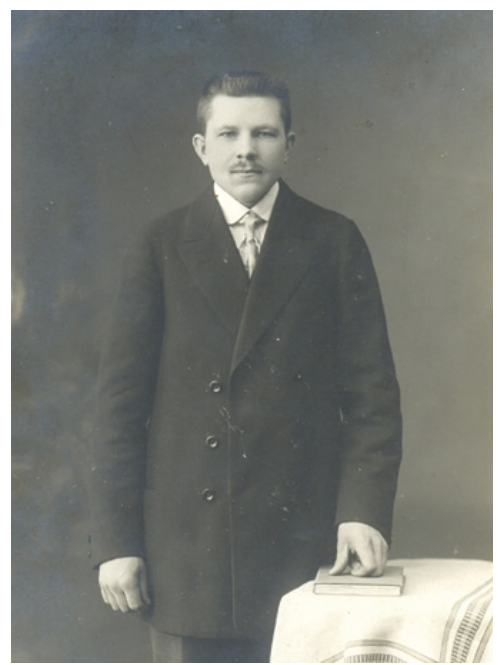

A. Mazurs was born in Prauliena, in the family of the owner of the Dobsalas house. He attended the parish school for four winters. At the beginning of the 20th century, a country guy went to Riga and probably started working for some carriage master. He later wrote in a questionnaire that he had studied the craft since 1902 [17]. In the early 1920s, the former citizen of Prauliena returned to Madona with an intention of setting up his own company. In 1923, in the town plan prepared by the architect, a graduate of Riga Polytechnic Institute (RPI; 1913) Arnolds Maidels (1884-1946), the undeveloped territory (plot of land F287) near Avotu Street was intended for the location of industrial enterprises. In 1924, A. Mazurs started to create his own workshop there. The work was started in an $8 \times 16$ m building. One third of the ground floor of the building was dedicated to a carpenter's workshop and the owner had a living room in the roof construction. The building plan was drawn by Gustavs Zosuls (1881-1933), an engineer and graduate of RPI (1910). The plan of the building, drawn by the construction technician Jülijs Treidass (1882-1945), foresaw spaces for drying trees and for steaming to prepare wooden parts for bending 
(used to bend carriage wheels and sled runners, some details for couches and sledges), which were separated from buildings where open fire was used.

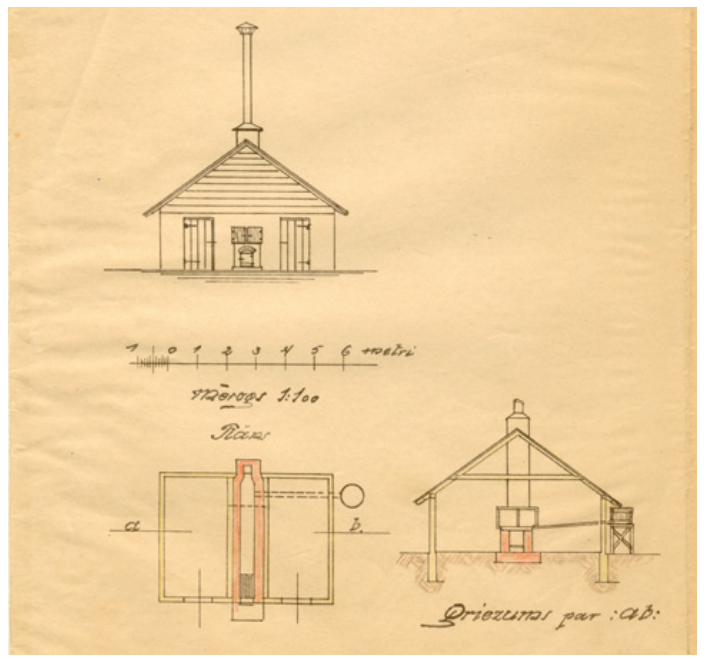

Figure 7. Project of wood steaming building for A. Mazurs' carriage workshop. Drawing by J. Treidass (1924).

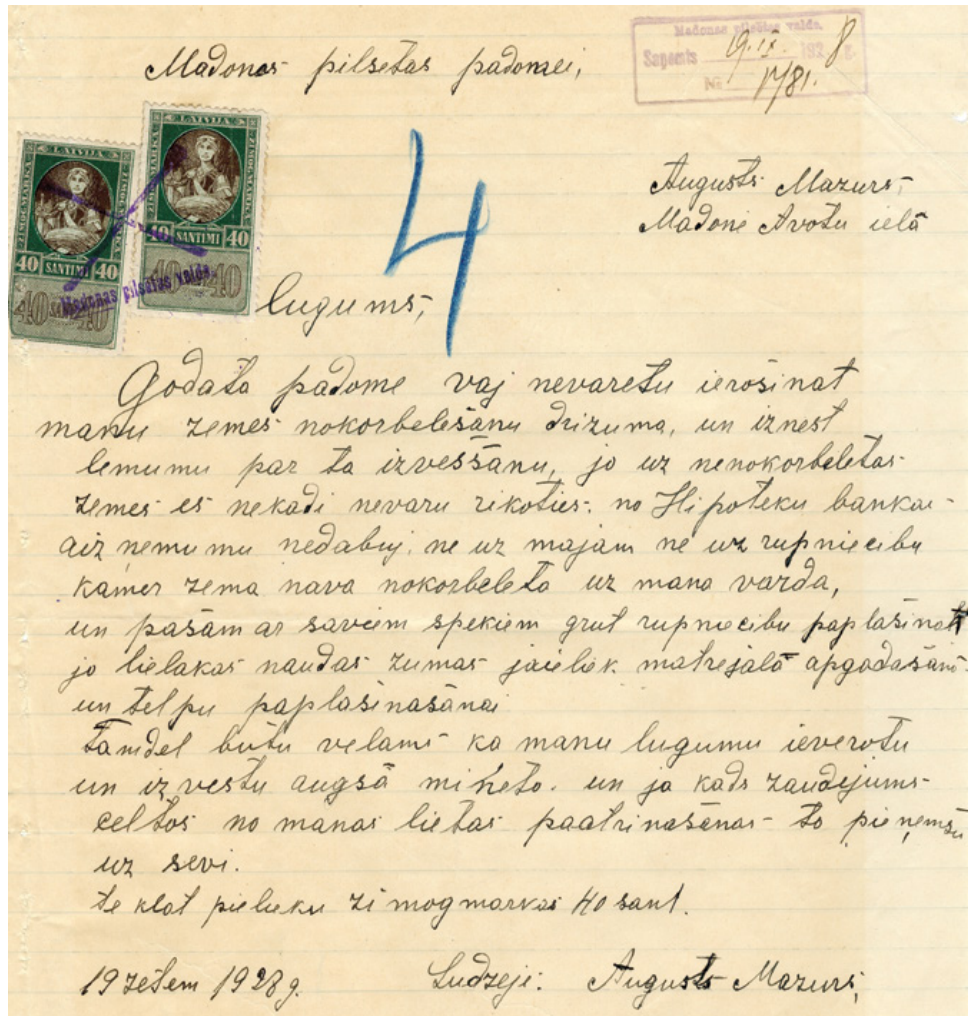

Figure 8. Petition by A. Mazurs on land corroboration (1928). 


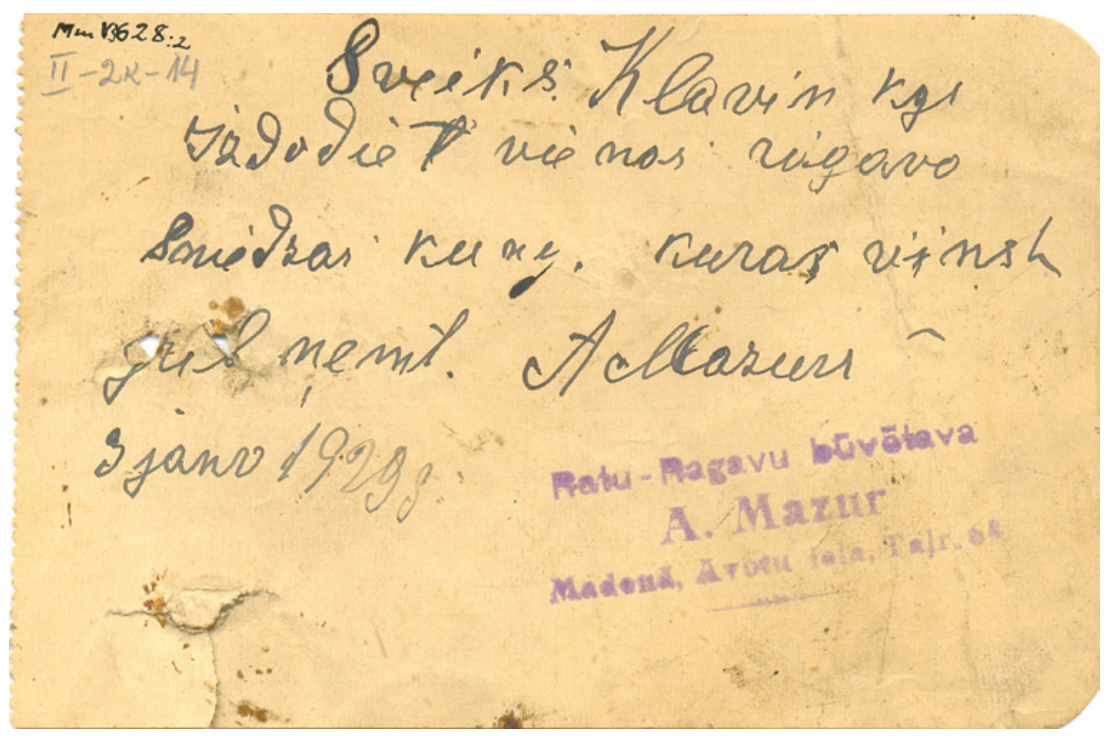

Figure 9. A. Mazurs'stamp on issuing of sleds (1929).

In 1929, a two-storey brick residential building was built on Avotu Street to the project of contractor Teodors Cìrulis (1898?-1963?) [18]. In petitions to the city council, the carriage maker repeatedly asked for the ownership of his land to be settled in order to receive a bank loan for the development of production. At the end of the 1920s, A. Mazurs married Kristīne Penǵerote (?-?). In their family a daughter Mãra and a son Juris were born.

The main products of $A$. Mazurs company were horse-drawn vehicles, but skis and children's sledges were also made, thus making better use of timber. Boys were able to learn how to make skis in primary school lessons [19]. In September 1936, during the Harvest Festival, an exhibition of Latgale region took place in Rēzekne. A. Mazurs offered special carriages for milk delivery to the dairy. The cans were placed on a lowered part between the wheels, thus making the placing of milk cans easier. Outside the dairy, an elevated ramp was usually installed to lift the cans out of the carts. The price of the exhibited carriages was 160 lats per unit. On the opening day, the exhibition was also visited by the President of Latvia Kārlis Ulmanis (1877-1942) who found the vehicle very good and even bought the exhibit [20]. At that time, the Madona area was one of the main dairy producing regions in Latvia.

There is no more information about the workshop employees. It is believed that at the beginning the carriage maker cooperated with blacksmith Jēkabs Klaviñš (?-?) who has been working in Madona since the beginning of the 20th century. It was concluded from the 1935 census 
data that besides mentioned workers Sprogi $i$ and J. Sausingš there were the following workers at A. Mazurs' workshop: carpenter Jānis Turks (1906-?) [21], blacksmiths father Ernests Fleišers (1880-?) and son Jānis Fleišers (1905-?), and blacksmith Voldemārs Ādamsons (1899-?) [22] who had trained (1919-1920) Kärlis Saulitis (?-?). Presumably, the three blacksmiths Aleksandrs Ananičs (1913-?), Voldemārs Elsons (1913-?), and Kärlis Iesalnieks (1904-?), who lived in A. Mazurs' house at 14 Avotu Street [23] in August 1941, worked in the adjoining carriage and sled workshop. Blacksmiths had an important role in the workshop.

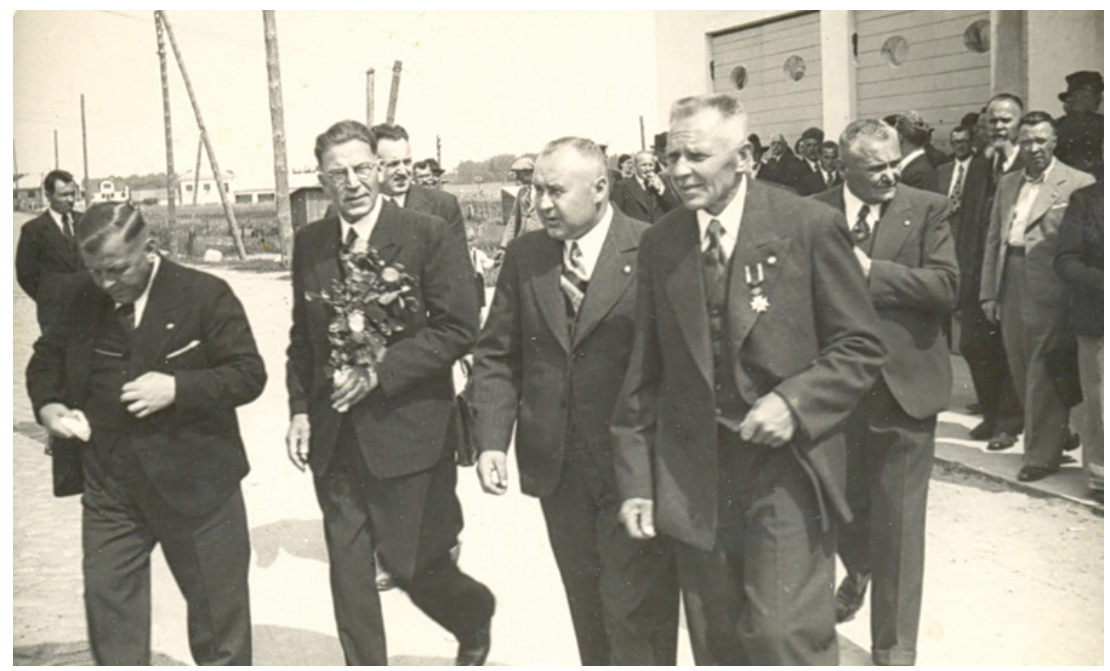

Figure 10. Madona Craftsmen Society flag on the consecration day. Second from the left -Head of the Latvian Chamber of Crafts Jānis Lukševics; fourth - Chairman of the Madona Craftsmen Society Augusts Mazurs (09.07.1938).

Already when one of the leaders of the Latvian Chamber of Crafts, A. Mazurs was among the founders of the Madona Craftsmen Society in January 1937 [24]. He headed this Society for less than eight years with a break (1940-1941) during the Soviet era. In 1938, the carriage maker was awarded the Cross of Recognition, Fifth Class.

The petition of the Soviet-era businessman of February 1941 is eloquent:

«To highly respected Executive Committee of the Madona city. Augusts Mazurs

b. in Madona, 14 Avotu Street

Request.

I am writing regarding the rent imposed on my carriage sledge workshop, 445 rubles a month, which I am not able to pay because the product consumers are rural farmers who are not able to pay high prices, therefore in recent months demand has decreased. You may know that for seventeen years I have worked as a real stakhanovite, even invented and built cars from old scrap and invented apparatus of high 
productivity, working day and night to improve and succeed in my work. And if you think that such a workshop is not needed, then do not stop me, a working person; then just say that I am not welcome. But if you think that my workshop should exist and produce, then I sincerely ask you to apply measures so that the workshop can exist and meet the needs of working farmers.

I sincerely ask you to give me a favourable answer regarding the above written.

Two lats in stamps are attached.

11. II. 41. Madona

Yours sincerely, A. Mazurs» [25].

The expropriation of the company could be considered as a response to the petition, it was included in industrial combine as a «Madona Carriage Workshop» by order of the County Executive Committee [26]. It was reprivatized the following autumn. During the German occupation, Central Council for Cooperation of Latvian Craftsmen was established. Madona citizen A. Mazurs was one of its leaders [27]. War conditions affected the work of craftsmen - access to raw materials was more limited, various army orders had to be fulfilled. For example, in the mechanical workshop of blacksmith and carpenter Pēteris Bicāls (1892-1971) in Kārzdaba «Rēzēni», where once bicycles were assembled, carriages were made for the needs of the German army [28].

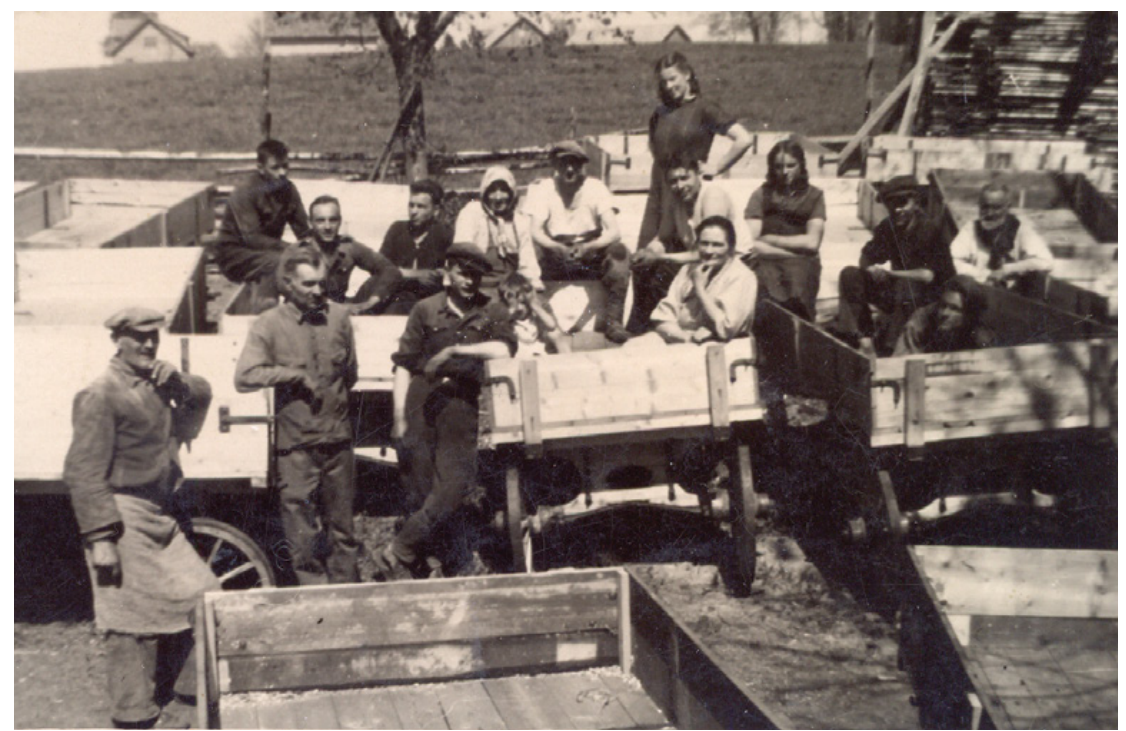

Figure 11. Carriages made in the workshop of P. Bicāls in Kārzdaba for the needs of the German army (1943). 


\section{Madona Carriage and Sled Workshop of Industrial Combine}

After the arrival of the Red Army in Latvia in 1944, the workshop was once again expropriated and included in the industrial combine, but the former owner A. Mazurs remained Head of it for almost six years. Immediately after World War II, various craftsmen were brought together under the "roof of the industrial combine»: leatherworkers, weavers, tailors, carpenters, shoemakers, clothes dyers, workers of mills, mechanical workshops and sawmill who had previously operated in Madona. A novelty was the scale repair workshop that was opened in the industrial combine. In the autumn of 1945, there were seven workers in the carriage workshop - the aforementioned Augusts Mazurs and Konstantīns Tominšs (?-?), Jūlijs Tūls (?-?), Jānis Vètra (?-?), and Antons Liepa (?-?). At that time, because there were no blacksmiths, the carriages were not sheeted [29]. In 1946, A. Mazurs designed a portable jigsaw with an electric motor of the size required to saw large blocks of oak to make hubs and spokes [30].

At the beginning of 1949, the carriage and sled workshop of the Madona industrial combine had a total of 15 employees, 10 of them in woodworking and five in the smithy [31]. The workshop was located in five different buildings. The list of mechanisms included long plane, band saw, circular saw, wood cutter, lathe, drill, metal press, mechanical hammer, and metal sheet scissors. Almost all mechanisms were either made on site or assembled from used parts with 50 or more percent wear. Five different electric motors were used as drives, one of which powered a fan.

Operation of the Madona industrial combine was subject to the existing economic planning of the Union of Soviet Socialist Republics (USSR), which envisaged a steady increase in production. The fiveyear (1946-1950) development plan of the Madona carriage and sled workshop was not fulfilled (Table 2).

Table 2

Development Plan and Production of the carriage and sled workshop of Madona industrial combine (1946-1950) [32]

\begin{tabular}{|c|c|c|c|c|c|c|}
\hline Production & Produced & \multicolumn{5}{|c|}{ Planned to produce (items) } \\
\hline (items) & \multicolumn{5}{|c|}{} \\
\hline Year & 1945 & 1946 & 1947 & 1948 & 1949 & 1950 \\
\hline Carriages & 72 & 280 & 400 & 600 & 800 & 1000 \\
\hline Wheels & 297 & 300 & 900 & 2500 & 2800 & 3000 \\
\hline Sleds & 118 & 360 & 500 & 550 & 600 & 700 \\
\hline
\end{tabular}


In December 1945, the price of the following products was set in the industrial combine: carriages -150 rubles, sleds -50 rubles [33].

In reality, the plans for the next five years turned out to be exaggerated in the years to come. The establishment of collective farms also reduced the demand.

Table 3

Quarterly Production Plan of Madona industrial combine in 1950 [34]

\begin{tabular}{|l|c|c|c|c|c|}
\hline Quarter & I & II & III & IV & Total (items) \\
\hline Carriages (items) & 96 & 144 & 112 & 48 & 400 \\
\hline
\end{tabular}

In April 1949, the first technical conference of the local industrial carriage industry took place in Madona, because it was recognized that the citizens of Madona are the best in this field in Latvia. Representatives of 12 counties arrived - managers of industrial combines, engineers, first-rate workers, and representatives of the Ministry of Local Industry (MLI) of the Soviet Socialist Republic of Latvia. A. Mazurs was awarded the MLI award at this conference. The improvement of production technologies and lowering of costs were discussed. There was also a small exhibition where the products of Jékabpils, Liepāja and Madona industrial combines could be seen. Deputy Minister Boriss Koškins (?-?) emphasized that the collectivisation of the countryside would place new demands on the production of carriages and highlighted the increasing need for pair-horse carriages [35].

Three months later, in July 1949, the Madona industrial combine reported to the County Executive Committee: «At the beginning of this year, significant number of finished products began to accumulate and significantly exceeded the standard of county industrial combine of Madona. This is due to the fact that local products because of the mass collectivization of farmers had no sales. In particular, the following products were not sold: carriages, sleds, wheels, lime, fruit marmalade, etc. Sales of these products have not improved so far, as the new collective farms do not buy these products due to lack of funds...» [36]. During this time, carriage wheels were made also in Madona forestry Zelgauska.

In the first half of the 1950s, it was still planned to produce about 500 carriages every year. The report of 1953 the Madona industrial combine states: 512 carriages were made instead of the planned 550; the plan was not fulfilled due to lack of materials [37].

It is clear that the need for carriages depended, to some extent, on the total number of horses, although there is no direct proportionality. During the Soviet period, after the establishment of collective farms, 
private individuals owned fewer and fewer horses and their number in the republic reduced by half.

Table 4

Number of horses in Latvia in different years [38; 39]

\begin{tabular}{|c|c|c|c|c|c|c|c|c|c|c|c|c|c|}
\hline 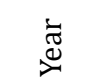 & $\underset{\sim}{\stackrel{\text { N }}{\sim}}$ & $\begin{array}{l}\stackrel{L}{N} \\
\stackrel{\sim}{\sim}\end{array}$ & $\begin{array}{l}\stackrel{\rho}{n} \\
\text { }\end{array}$ & $\begin{array}{l}\stackrel{L}{m} \\
\stackrel{\sim}{\sim}\end{array}$ & $\underset{\sim}{\stackrel{\text { J }}{\sigma}}$ & \begin{tabular}{l}
0 \\
\multirow{\sigma}{\sigma}{}
\end{tabular} & $\begin{array}{l}\text { 고 } \\
\stackrel{-}{\sim}\end{array}$ & $\begin{array}{l}\text { 오 } \\
\stackrel{2}{\sim}\end{array}$ & $\begin{array}{l}\stackrel{\circ}{ } \\
\stackrel{2}{\sim}\end{array}$ & $\begin{array}{l}\text { ᄂి } \\
\text { ڤ̆ }\end{array}$ & $\begin{array}{l}\stackrel{2}{N} \\
\text { م }\end{array}$ & $\begin{array}{l}\stackrel{L}{\hat{N}} \\
\stackrel{\sigma}{\sim}\end{array}$ & $\begin{array}{l}\stackrel{\circ}{\mathscr{2}} \\
\stackrel{\sim}{\sim}\end{array}$ \\
\hline 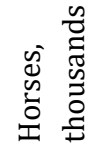 & 규 & ก๊ & $\begin{array}{l}\text { ิㅗ } \\
\text { m}\end{array}$ & $\begin{array}{l}\text { L } \\
\infty \\
m\end{array}$ & ๙2 & $\underset{m}{\text { m }}$ & ๙ิ & 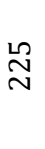 & $\underset{\neg}{\stackrel{+}{二}}$ & 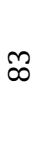 & gి & $\stackrel{\text { q }}{q}$ & m \\
\hline
\end{tabular}

In the middle of 1950, A. Mazurs was fired from the position as a manager. Initially, the workshop was managed by an employee named Vittinš, then a blacksmith $K$. Saulitis, who started working there in the 1930s. Newspaper «Madonas Arājs» severely criticized A. Mazurs: «The former workshop manager Mazurs, its former owner .. was unfamiliar with the principles of socialist production. It is clear that in the times of bourgeois Latvia it is customary by exploiting other people to put a lion's share of money in a personal pocket; Mazurs was not trying to find untapped production opportunities» [40]. According to the laws of that time, the time of working in one's own company was not included in the length of service. Thus, the 65-year-old man stayed in the workshop as a blacksmith and continued to earn his pension. In the house that he had built, he rented an apartment from the Apartment Management Board. Four years later, A. Mazurs' work was praised: «Many of the workers in the carriage-sled workshop have also become real owners of their company. To mark one of the oldest workers in the workshop - blacksmith Augusts Mazurs, who has been working in the industrial combine since 1944, and in this industry in general - for more than 50 years. During this time, he was busy working on new proposals and suggestions, but without the necessary engineering assistance, it was not always possible to implement them. His latest invention was a cylinder-scissors had a wide range of application in the processing of car parts. They makes it possible to perform up to 6 work operations by changing individual parts of the top plate, which significantly simplifies and speeds up the existing processing of car trim and saves up to 3500 rubles per year» [41].

It must be said that differing views in various press articles was characteristic of that time. For example, at the beginning of 1956, the newspaper noted that in the previous year the staff of the carriage and 
sled workshop had achieved the best results thanks to its manager Sergejs Čerevko (?-?) who had been in the post for the last four months [42]. In the autumn, however, the same $S$. Čerevko was accused of not building a shed for storing finished products, the carriages were soaking in rain and on the pay day, the workshop manager was having a drink with the workers [43].

Figure 12. In the carriage-sled workshop of Madona industrial combine. Photo by J. Lublinskis (1956).

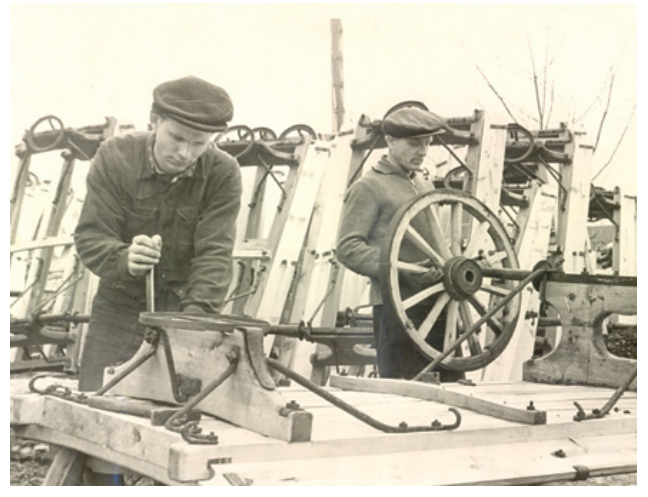

In 1959, new production facilities were built for the industrial combine in the eastern outskirts of Madona, and a carriage-sled workshop was set up there, which began to reduce the workload. This is also related to the decrease in the number of horses in Latvia.

In the mid-1960s, Mazsalaca became the main centre the production of single-horse carriages in Latvia. On 24 April 1966, the carriage accessories factory «Mazsalaca» of the Ministry of Local Industry of the Latvian SSR was established on the basis of the Mazsalaca furniture workshop of Valmiera furniture factory [44]. It should be noted that the furniture workshop had produced carriages and sleds before. In December 1971, the factory became a branch of the Association for the Production of Furniture for Schools and Children's Institutions «Mazsalaca» of Ministry of Local Industry's, where mainly carriages and also clothes hangers were produced. In April 1968, the Mazsalaca factory took over the equipment for making carriage wheels from the Bauska household service combine [45].

The produced wooden wheels had two diameters $-630 \mathrm{~mm}$ (front wheels) and $720 \mathrm{~mm}$ (rear wheels), and in a year their production as spare parts was five times bigger than that of carriages. Since 1970, the reports mention separately carriages with rubber tires and carriages with aviation wheels. The workshops of the Madona branch of the Latvian Agricultural Machinery (LAM) in Sauleskalns had a special workshop, where discs, which were assembled from used aircraft tires, 
were made for Mazsalaca [46]. Aviation equipment was produced for heavy loads, it had stricter requirements.

Table 5

Production of horse-drawn vehicle accessories in factory «Mazsalaca»

(1965-1977) [47]

\begin{tabular}{|c|c|c|c|c|c|c|c|c|c|}
\hline $\begin{array}{l}\text { Name of production / } \\
\text { year }\end{array}$ & 능 & ஜே & פి & م & $\stackrel{1}{\circ}$ & $\stackrel{N}{\hat{N}}$ & $\stackrel{n}{\hat{N}}$ & 市 & 今ે \\
\hline $\begin{array}{l}\text { Carriages with wooden } \\
\text { wheels, items }\end{array}$ & 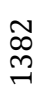 & 농 & 守 & $\stackrel{m}{7}_{\tilde{H}}$ & 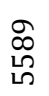 & \begin{tabular}{l}
$\infty$ \\
$\stackrel{+}{+}$ \\
\multirow{+}{+}{}
\end{tabular} & $\stackrel{\text { L }}{\stackrel{1}{+}}$ & $\stackrel{\circ}{\stackrel{+}{N}}$ & 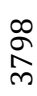 \\
\hline $\begin{array}{l}\text { Carriages with rubber } \\
\text { tires, items }\end{array}$ & & & & 广্ & 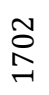 & $\stackrel{\text { L }}{\infty}$ & 梁 & $\stackrel{ }{\stackrel{1}{+}}$ & 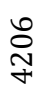 \\
\hline Wooden wheels, items & & $\begin{array}{l}\text { 로 } \\
\text { ำ }\end{array}$ & $\begin{array}{l}\infty \\
\stackrel{\circ}{\circ} \\
\text { ํํํ }\end{array}$ & & & & 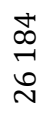 & $\begin{array}{l}\stackrel{+}{+} \\
\stackrel{m}{m}\end{array}$ & $\begin{array}{l}\infty \\
\stackrel{\infty}{N} \\
\stackrel{m}{m}\end{array}$ \\
\hline Sleds, items & $\vec{\sigma}$ & 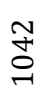 & & & & & 官 & $\begin{array}{l}\circ \\
\mathscr{2} \\
\stackrel{0}{\infty}\end{array}$ & $\begin{array}{l}\text { 논 } \\
\text { 는 }\end{array}$ \\
\hline
\end{tabular}

On 1 January 1968, there were 96 workers, nine engineers and seven servants in the factory, 31 employee was hired in the previous year, and 28 were released. In 1972, carriages with wooden wheels cost 82 rubles, carriages with rubber tires - 233 rubles, carriages with aviation wheels - 350 rubles, sleds -32 rubles [48]. The smallest wooden wheel cost 8.7 rubles, the largest -9.8 rubles. During this time, the company had 136 employees.

In 1977, carriages, sleds and their parts from Mazsalaca were handed over to LAM district associations and forestry. The production was also supplied to the Agricultural Machinery Associations of the Soviet Socialist Republic of Estonia (in Estonia in the 1960s the carriages were manufactured in the carriage accessories workshop of the Pärnu Woodworking Combine) and to the consumer associations of the Pskov region [49]. It is noted, however, that not all LAM district associations wanted to receive the previously allocated products, for example, the Madona branch has given up 230 sleds. The production of carriages in Mazsalaca continued in the 1980s. 


\section{Conclusions}

In Latvia, in the first half of the 20th century, horse-drawn vehicles had an important role in local transportation and were the main transport providers. The production, repair and maintenance of horsedrawn carriages were provided by local craftsmen and blacksmiths. In the Republic of Latvia and its territory during the interwar period and also in the decade after World War II, horse-drawn vehicles had an important role in the production and management of rural areas. Horses were used in various jobs on farms, and later, after World War II, in collective farms, because there were few tractors and cars and these vehicles could not provide all the transport logistic. Carriages and sleds were made on site and met demand, while most cars and other machinery were imported with higher costs. Later, the number of motor vehicles gradually increased and the use of horse-drawn carriages decreased. Carriage production also decreased as they were replaced by other, more modern vehicles.

\section{REFERENCES}

[1] Jānītis, J. Kravu pārvadāšanas darbi lauksaimniecībā un šo darbu uzlabošanas iespējas. Lauksaimniecības Mēnešraksts, 1938. gads, jūlijs, 404.-423. lpp.

[2] Bīlenšteins, A. Latviešu koka iedzīves priekšmeti. Rīga: Jumava, 2007, 361.-371. lpp.

[3] Āboliṇš, J. Lauksaimniecības darbu tehnika. Latvijas zeme, zemnieki un vinuu darbs. Rīga: Lauksaimniecības pārvalde, 1940, 423. lpp.

[4] Latviešu literārās valodas vārdnīca. 6. sēj. 2. daḷa. Rīga: Zinātne, 1987, 541. lpp.

[5] Āboliṇš, J. Darba rati Latvijas lauksaimniecībā. Rīga: LU Lauksaimniecības fakultātes Lauksaimniecības mašīnu kabinets, 1935, 11., 93. lpp.

[6] Valdības rīkojumi un pavēles. Cenas karaspēka vajadzībām mobilizējamiem vai rekvizējamiem zirgiem, transporta līdzekḷiem. Valdības Vēstnesis, 1923. gada 13. marts, Nr. 54, 1. lp.

[7] Katalogs «Pirmā Rīgas ratu atsperu un asu fabrika I. M. Kraner» Rīgā, Cēsu ielā 9. Cenu rādītājs 1935./36. gadam atsperēm, asīm, visādiem ratu piederumiem. MNM25808.

[8] Pieprasiet universāltipa darba ratus. Zemgales Balss, 1937. gada 5. jūlijs, 5. lpp.

[9] Latvijas statistiskā gada grāmata. Rīga: Valsts statistiskā pārvalde, 1925-1939.

[10] Dukāts, Ā. Amatniecības uzṇēmumu skaits. Ekonomists, 1940. gada 1. februāris, Nr. 3, 24. lpp. 
[11] Latvijas buru kuǵa «Fridrich» avarija. Jūrnieks, 1931. gada 1. decembris, Nr. 12, 381. lpp.

[12] Latvijas Nacionālā arhīva Latvijas Valsts vēstures arhīvs (turpmāk - LNA LVVA) 1693. f., 1. apr., 51. 1., 23. lp.

[13] [Ratnieks]. Latviešu konversācijas vārdnīca. 18. sēj. Rīga: A. Gulbja apgādībā, 1938, 35005. sleja.

[14] Ziṇas par jaunu biedru uzṇemšanu Madonas amatnieku biedrībā. LNA LVVA 1693. f., 1. apr., 1190., 1220., 1255., 1293. l.

[15] Lazdonas luterāṇu draudzē dzimušie. LNA LVVA 235. f., 15. apr., 597. l., 7. lp.

[16] Bertas Sproges atminnas. 1987. gads. MNM21360.

[17] A. Mazura anketa ar dzīves datiem. LNA LVVA, 1693. f., 1. apr., 1190. l., 31. lp.

[18] T. Cīruḷa projektētās ēkas Madonā dokumentācija. MNM37650.

[19] Panteḷejevs, A. Zēnu rokdarbi. Rīga: Valters un Rapa, 1935, 117.-121. lpp.

[20] Zemes saimnieks 2 dienas pie Latgales arājiem. Brīvā Zeme, 1936. gada 15. septembris, Nr. 209, 3. lpp.

[21] Tautas skaitīšanas dokumenti, 1935. gads. LNA LVVA 1308. f., 9. apr., 10040. l., 94. lp.

[22] Tautas skaitīšanas dokumenti, 1935. gads. LNA LVVA 1308. f., 9. apr., 10038. 1., 81., 104. lp.

[23] Tautas skaitǐšanas dokumenti, 1941. gads. LNA LVVA 1308. f., 15. apr., 2901. 1., 27. lp.

[24] Madonas amatnieku biedrības dokumenti. LNA LVVA 1693. f., 1. apr., 1190. l., 39. lp.

[25] A. Mazura lūgums Madonas pilsētas izpildu komitejai. Latvijas Nacionālā arhīva Latvijas valsts arhīvs 1312. f., 1. apr., 30. 1., 46. lp.

[26] Madonas apr. izpildu komitejas Rūpniecības kombināta 13. rīkojums. Latvijas PSR Augstākās Padomes Prezidija Ziṇotājs, 1941. gada 5. jūnijs, Nr. 130, 6. lpp.

[27] Amatnieku kopdarbība. Daugavas Vanagi, 1942. gada 18. septembris, Nr. 26, 2. lpp.

[28] P. Bicāla darbnīcā Kārzdabā gatavotie rati vācu armijas vajadzībām. MNM25595:1.

[29] Ratu - ragavu darbnīcā. Madonas Arājs, 1945. gada 17. oktobris, Nr. 103, 2. lpp.

[30] Darbnīcas vadītājs - racionalizators. Cīṇa, 1947. gada 25. janvāris, Nr. 21, 3. lpp.

[31] Pārskats par Madonas apriṇk ķa rūpkombinātu uz 1949. gada 1. janvāris. Cēsu zonālais valsts arhīvs (turpmāk - CZVA) 608. f., 1. apr., 19. l., 19. lp.

[32] Madonas rūpkombināta ratu un ragavu darbnīcas darba plāns un saražotais 1946.-1950. gadam. CZVA 60. f., 1. apr., 47. l., 1. lp.

[33] Madonas rūpkombināta ražojumu cenrādis 1945. gadam. CZVA 60. f., 1. apr., 49. l., 30. lp.

[34] Madonas rūpkombināta ratu ražošanas plāns 1950. gadā. CZVA 60. f., 1. apr., 54. l., 46. lp. 
[35] Pirmā republikas vietējās rūpniecības tehniskā konference Madonā. Madonas Arājs, 1949. gada 8. aprīlis, Nr. 42, 2. lpp.

[36] Madonas rūpkombināta ziṇojums apriṇksa izpildu komitejai, 1949. gada jūlijs. CZVA 558. f., 1. apr., 102. l., 1. lp.

[37] Madonas rūpkombināta 1953. gada atskaite par ratu izgatavošanu. CZVA 118. f., 1. apr., 214. l., 10. lp.

[38] Latvijas statistiskā gada grāmata. Rīga: Valsts statistiskā pārvalde, 1921, 1926, 1931, 1936.

[39] Latvijas PSR tautas saimniecība. Rīga: Valsts Statistikas izdevniecība, 1957, 1971, 1990.

[40] Kalējs, J. Kas vēl kavē ražošanu ratu - ragavu darbnīcā. Madonas Arājs, 1950. gada 28. septembris, Nr. 119, 2. lpp.

[41] Rūpniecības strādnieki par godu 1.maijam. Stars, 1954. gada 21. aprīlis, Nr. 48, 1. lpp.

[42] Daugavietis, P. Strādāsim labāk. Stars, 1956. gada 1. janvāris, Nr. 1, 1. lpp.

[43] Lācis, T. Nedaudz par rūpniecības kombināta ikdienu. Stars, 1956. gada 25. oktobris, Nr. 127, 2. lpp.

[44] Latvijas PSR Vietējās rūpniecības ministrijas pavēle. Valmieras zonālais valsts arhīvs (turpmāk VaZVA) 813. f., 1. apr., 17. 1., 1. lp.

[45] Materiālu pārṇemšanas akts. VaZVA 813. f., 1. apr., 20. l., 1. lp.

[46] Kārkliṇš, U. Mehānisko darbnīcu kolektīvā. Stars, 1971. gada 17. jūnijs, Nr. 72, 2. lpp.

[47] Pajūgu piederumu rūpnīcas «Mazsalaca» atskaites. VaZVA 813. f., 1. apr., 18., 24., 44., 49. l.

[48] Skolu un bērnu iestāžu apvienības Mazsalacas filiāles gada atskaites, VaZVA 813. f, 1. apr., 44. l., 20. lp.

[49] Paskaidrojums pie 1977. gada atskaites. VaZVA, 813. f., 1. apr., 49. l., 1.-2. lp.

\section{SOURCES OF ILLUSTRATIONS}

Figure 1. Broce, J. K. Zīmējumi un apraksti. 1. sēj. Rīga: Zinātne, 1992., 109. lpp.

Figure 2. Madonas novadpētniecības un mākslas muzejs (turpmāk - MNM)

MNM 43015:5.

Figure 3. MNM 43603.

Figure 4. Āboliṇš, J. Daži darba ratu paraugi. Latvijas Lauksaimnieks, 1936. gada 1. decembrī, Nr. 23, 659. lpp.

Figure 5. MNM43026.

Figure 6. MNM16771:1.

Figure 7. MNM37650:20/42.

Figure 8. MNM37650:20/8.

Figure 9. MNM3628:2.

Figure 10. Māras Mazures privātais arhīvs. 


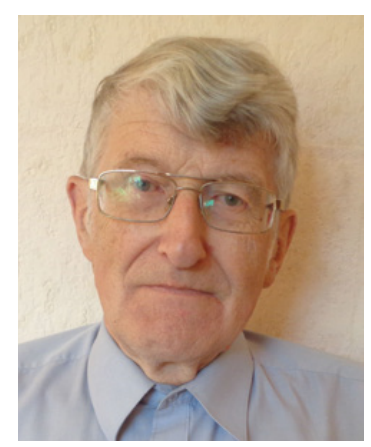

INDULIS ZVIRGZDIN̦Š, Mg. hist. (1996, University of Latvia), was a senior researcher at the Madona Museum of Local History and Art, member of the Latvian Association of History of Science. His main academic interests include the history of Madona and Madona District. He is the author of many publications.

Address: 12 Skolas iela, Madona, LV-4801, Latvia

E-mail: zviindulis6@inbox.lv

Indulis Zvirgzdiņš

\section{Zirgvilkmes ratu ražošana Latvijā 20. gadsimtā}

Pagājušā gadsimta pirmajā pusē ratu izgatavošanā sadarbojās kokamatnieki un kalēji, kas vairumā gadījumu strādāja individuāli. Darbojās arī lielāki uzṇēmumi, galvenokārt pilsētās. Galvenā uzmanība pievērsta Madonas apkārtnei. Kā piemērs izmantota Augusta Mazura (1885-1975) ratu un ragavu darbnīca, kas bija apvidū ievērojamākā. Tā tika izveidota 1924. gadā un darbu turpināja arī padomju laikā.

Zirgvilkmes rati vietējos pārvadājumos bija galvenais transporta līdzekḷu veids Latvijas Republikā un tās teritorijā arī desmitgadē pēc Otrā pasaules kara. Vēlāk pakāpeniski pieauga autotransporta loma. Ratus un ragavas gatavoja uz vietas, vairums automašinnu tika ievestas.

Atslēgas vārdi: zirgvilkmes transports, ratnieki, kokapstrāde, Latvijas Amatniecības kamera, Augusts Mazurs. 